\title{
Cultured Human Synovial Fibroblasts Rapidly Metabolize Kinins and Neuropeptides
}

\author{
Joan M. Bathon, * David Proud, ${ }^{*}$ Shigehiko Mizutani, ${ }^{5}$ and Patrick E. Ward" \\ Divisions of * Rheumatology and ${ }^{\ddagger}$ Clinical Immunology, Department of Medicine, The Johns Hopkins University School of Medicine, \\ Baltimore, Maryland 21224; $\$$ Department of Obstetrics and Gynecology, Nagoya University, Nagoya, Japan; and "Department of \\ Physiology, The Ohio State University, Columbus, Ohio 43210
}

\begin{abstract}
Kinins and substance $P$ have been implicated in the pathogenesis of inflammatory arthritis by virtue of their abilities to induce vasodilation, edema, and pain. The relative biological potencies of these peptides in vivo would depend at least in part upon their rates of catabolism in the joint. We hypothesized that human synovial lining cells may regulate intraarticular levels of kinins and neuropeptides via degradation by cell surface-associated peptidases. We exposed intact human synovial fibroblasts to kinins and substance $P$, in the presence or absence of specific peptidase inhibitors, and measured the amount of intact substrate remaining and degradation product(s) generated over time. Aminopeptidase M (AmM; EC 3.4.11.2), neutral endopeptidase-24.11 (NEP-24.11; EC 3.4.24.11), and dipeptidyl(amino)peptidase IV (DAP IV; EC 3.4.14.5) were identified on the cell surface of synovial cells. Bradykinin degradation was due entirely to NEP-24.11 (1.39 $\pm 0.29 \mathrm{nmol} / \mathrm{min}$ per well). Lysylbradykinin was also degraded by NEP-24.11 $(0.80 \pm 0.19 \mathrm{nmol} / \mathrm{min}$ per well $)$; however, in the presence of phosphoramidon, AmM-mediated conversion to bradykinin (3.74 $\pm 0.46 \mathrm{nmol} / \mathrm{min}$ per well) could be demonstrated. The combined actions of NEP-24.11 $(0.93 \pm 0.15 \mathrm{nmol} / \mathrm{min}$ per well $)$ and DAP IV $(0.84 \pm 0.18 \mathrm{nmol} / \mathrm{min}$ per well $)$ were responsible for the degradation of substance P. AmM (2.44 \pm 0.33 $\mathrm{nmol} / \mathrm{min}$ per well) and NEP-24.11 (1.30 $\pm 0.45 \mathrm{nmol} / \mathrm{min}$ per well) were responsible for the degradation of the opioid peptide, [ $\left.\mathrm{Leu}^{5}\right]$ enkephalin. The identity of each of the three peptidases was confirmed via synthetic substrate hydrolysis, inhibition profile, and immunological identification. The profiles of peptidase enzymes identified in cells derived from rheumatoid and osteoarthritic joints were identical. These data demonstrate the human synovial fibroblast to be a rich source of three specific peptidases and suggest that it may play a prominent role in regulating peptide levels in the joint. (J. Clin. Invest. 1992. 90:981-991.) Key words: arthritis • kinins • peptidases • substance $P$ • synovium
\end{abstract}

\section{Introduction}

Rheumatoid arthritis is a chronic inflammatory disease that is characterized by the erosion and degradation of cartilage and

Address reprint requests to Dr. Bathon, Room 5A.24, The Johns Hopkins Asthma and Allergy Center, 5501 Hopkins Bayview Circle, Baltimore, MD 21224.

Received for publication 4 September 1991 and in revised form 25 February 1992.

J. Clin. Invest.

(C) The American Society for Clinical Investigation, Inc.

0021-9738/92/09/0981/11 $\$ 2.00$

Volume 90, September 1992, 981-991 bone, resulting in joint instability and chronic pain. Several small peptides, most notably kinins and substance $P$, have attracted recent interest as possible contributors to the pathogenesis and/or propagation of RA by virtue of their potent abilities to induce vasodilation, edema, and pain $(1,2)$.

Bradykinin and lysylbradykinin are small peptides liberated from alpha ${ }_{2}$-globulins, called kininogens, by the action of proteolytic enzymes, referred to as kallikreins. The presence of kinins in rheumatoid synovial fluid has been confirmed by several investigators (3-5) and these levels appear to exceed those found in synovial fluids of noninflammatory arthropathies such as osteoarthritis (OA) ${ }^{1}$ and trauma (5). The concept that these peptides contribute to the destructive process in the rheumatoid joint is supported by the observations that kinins induce an acute inflammatory response when injected into canine knees (5) and induce bone resorption in, and prostanoid release from, articular tissues in vitro $(6,7)$.

Substance $P$, an 11-amino acid peptide neurotransmitter, is released from the peripheral terminals of nociceptive afferent neurons upon antidromic stimulation. Its presence has been confirmed in human rheumatoid synovial fluid (8) and immunohistochemical studies have demonstrated the presence of substance P-containing nerves in synovia from human subjects with RA $(9,10)$ and in synovia from normal and arthritic animals $(11,12)$. Furthermore, intraarticular infusion of substance $P$ exacerbated joint injury in adjuvant-induced arthritis in rats, as evidenced by an increase in bony erosions and joint space narrowing and a decrease in bone density (13). Finally, substance $P$ is capable of stimulating the release of other inflammatory mediators, including prostanoids, IL-1, and histamine, from a variety of cells (14-17) and can itself function as an immune-modulating agent $(2,18)$.

Despite the convincing evidence demonstrating the presence and proinflammatory functions of kinins and substance $P$ in the joint, little is known regarding the mechanisms by which the actions of these peptides are regulated in this organ. In general, enzymatic catabolism represents a major mechanism by which biological activity of small peptides is regulated (19). Since the amount of peptidase activity in a target tissue will influence its capacity to respond to a peptide (20), and since the development of potent peptide antagonists that are based upon modifications of the parent molecule must take into consideration stability from enzymatic degradation $(20,21)$, iden-

1. Abbreviations used in this paper: $\mathrm{ACE}$, angiotensin-converting enzyme; AmA, AmM, and AmN, aminopeptidases A, M, and N; CPN, carboxypeptidase N; DAP IV, dipeptidyl (amino)peptidase IV; MERGETPA, DL-2-mercaptomethyl-3-guanidinoethylthio-propanoic acid; NEP-24.11, neutral endopeptidase-24.11; OA, osteoarthritis; ZIN$\mathrm{COV},[2,(N$-hydroxy-carboxamido $)$-4-methylpentanoyl-L-alanyl-glycine amide ]. 
tification and characterization of peptidase activities in the joint seem warranted.

Previous reports of peptidase activities in articular tissues are scarce, are based predominantly on immunoreactivity rather than on specific functional activity, and/or fail to identify the cellular source of the observed activity (22-25). We have observed previously that bradykinin is rapidly degraded upon exposure to human synovial fibroblasts (7). We hypothesize, therefore, that this human synovial lining cell may serve as an important regulator of peptide levels in the joint via degradation by cell surface-associated peptidases. The synovial lining is in a strategic position to perform this function since it lines the joint cavity, thus giving it access to synovial fluid peptides. Furthermore, the punctuation of synovium by small blood vessels would provide a route of delivery of kinins to the tissue and joint space (26), and substance $P$-containing nerves are found in close association with the synovial lining layer (9-11). In RA this lining layer is greatly hypertrophied (26) and its potential peptide-degrading capabilities, relative to a noninflamed joint, may thereby be greatly magnified.

In these studies, we have examined the ability of the human synovial fibroblast to metabolize kinins and substance P. Through the use of specific enzyme inhibitors and the analysis of specific metabolites generated, we sought to identify the synovial cell peptidase(s) responsible for, and the relative contribution of each to, the metabolism of kinins and substance P. In addition, we have compared the peptidase profile identified in synovial cells derived from patients with the inflammatory arthropathy RA to that of cells derived from patients with the relatively noninflammatory arthropathy OA.

\section{Methods}

Reagents. The following materials were purchased: bradykinin, lysylbradykinin, $o$-phenanthroline, EDTA, amastatin, bestatin, puromycin, phosphoramidon, alanyl-, leucyl-, arginyl-, $\alpha$-glutamyl- and glycylprolyl-naphthylamides, (piperazine- $N, N^{\prime}$ bis [2-ethanesulfonic acid]) (PIPES), and Tris buffers (Sigma Chemical Co., St. Louis, MO); substance $\mathrm{P}$ and diprotin A (Peninsula Laboratories, Belmont, CA); DME, FCS, penicillin/streptomycin, trypsin, PBS, and amphotericin B (Gibco Laboratories, Grand Island, NY); six-well polystyrene culture dishes (VWR Scientific, Bridgeport, NJ); captopril (SquibbNovo, Inc., Princeton, NJ); MERGETPA (DL-2-mercaptomethyl-3guanidinoethylthiopropanoic acid), ZINCOV ([2-( $N$-hydroxy-carboxamido)-4-methylpentanoyl-L-alanyl-glycine amide]); dansyl-DAla-Gly-pNO ${ }_{2}$-Phe-Gly (Calbiochem-Behring, San Diego, CA); mAbs recognizing CD10/neutral endopeptidase-24.11 (NEP-24.11) (J5; $\left.\mathrm{IgG}_{2 \mathrm{a}}\right), \mathrm{CD} 13$ /aminopeptidase $\mathrm{M}(\mathrm{AmM})\left(\mathrm{MY} 7 ; \mathrm{IgG}_{1}\right)$ and $\mathrm{CD} 26 /$ dipeptidyl (amino) peptidase IV (DAP IV) ( Ta 1; IgG 1 ) (Coulter Electronics Inc., Hialeah, FL). The following were kind gifts: recombinant IL-1 $\alpha$ (Immunex, Seattle, WA); bradykinin [1-7] and Phe-Arg (Drs. Regoli and Drapeau, Sherbrooke University, Sherbrooke, Quebec). Purified AmM (AmM) and AmM antisera were prepared by one of us (Dr. Mizutani) as previously described (27).

Patient population. Human synovial tissue was obtained from the knees and hips of patients who were undergoing surgical synovectomy or total joint replacement. The patient population consisted of $6 \mathrm{pa}-$ tients with RA and 12 patients with OA. Diagnoses were confirmed either by examination of the patient by one of the investigators (Dr. Bathon) or by chart review and contact with the primary rheumatologist. All patients with RA had either definite or classical disease as defined by criteria of the American College of Rheumatology (28). Similarly, patients with OA fulfilled published criteria for this disease (29). Of the six RA patients, five were maintained on low-dose prednisone ( $\leq 10 \mathrm{mg}$ daily), four on a nonsteroidal antiinflammatory drug, and one each on methotrexate, hydroxychloroquine, and sulfasalazine. Of the 12 patients with OA, 6 were taking a nonsteroidal antiinflammatory drug before surgery.

Synovial cell culture. Synovial cell cultures were established from the adherent cells of collagenase-dispersed synovial fragments or by outgrowth from synovial explants, as previously described $(7,30)$. Synovium was dissected free from surrounding tissues, minced into $2-3-\mathrm{mm}^{2}$ fragments, and enzymatically dissociated with $3 \mathrm{mg} / \mathrm{ml}$ of type 2 collagenase (Worthington Biochemical Corp., Freehold, NJ) in DME for 30-60 min. The resulting cell suspension was centrifuged, washed twice with PBS, and the pellet resuspended in DME supplemented with $20 \%$ FCS (DME/20\% FCS), penicillin ( $100 \mathrm{U} / \mathrm{ml})$, streptomycin $(100 \mu \mathrm{g} / \mathrm{ml})$, and amphotericin B $(2.5 \mu \mathrm{g} / \mathrm{ml})$. Nonadherent cells were removed at $24 \mathrm{~h}$ by washing; adherent cells were allowed to grow to confluence and were passaged with $0.25 \%$ trypsin. Where specimens were too small for enzymatic dispersion, adherent synovial cells were grown directly from minced explants. Both culture techniques result (after the first or second passage in enzymatically dispersed samples) in a relatively homogeneous fibroblast-like population of cells (31). Third- to sixth-passage cells were seeded in six-well polystyrene culture dishes at a density of $0.375-0.5 \times 10^{6}$ cells $/$ well for enzyme assays or in 100 -mm polystyrene culture dishes at a density of $2 \times 10^{6}$ cells for flow cytometry studies and were allowed to grow to confluence.

Enzyme assays in intact cells. Studies of peptide hydrolysis by intact synovial cells were conducted on confluent monolayers of cells in six-well culture dishes. Spent medium was removed and the cells were washed twice with $2 \mathrm{ml}$ of isosmolar PGCM buffer (PIPES with glu-

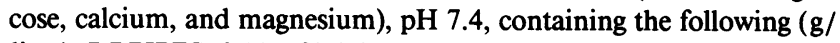
liter): 7.7 PIPES, $6.4 \mathrm{NaCl}, 0.37 \mathrm{KCl}, 1.0$ glucose, $0.29 \mathrm{CaCl}_{2}$, and 0.20 $\mathrm{MgCl}_{2}$. Peptide $(50 \mu \mathrm{M})$ was added in a final volume of $1 \mathrm{ml}$ of this buffer, in the presence or absence of peptidase inhibitors. In experiments conducted to detect carboxypeptidase N (CPN; EC 3.4.17.3) activity, $100 \mu \mathrm{M} \mathrm{CoCl}_{2}$ was also added to the buffer. Aliquots of supernatant were removed at varying times, boiled for $5 \mathrm{~min}$ to terminate the reaction, chilled in an ice bath for $5 \mathrm{~min}$, and centrifuged for $30 \mathrm{~s}$ in a tabletop centrifuge. Supernatants were frozen at $-70^{\circ} \mathrm{C}$ for subsequent HPLC analysis. Peptide hydrolysis was determined by the decrease in substrate (e.g., bradykinin) and the increase in products (e.g., bradykinin [1-7] and Phe-Arg). Since the average number of cells per well in these experiments was relatively constant $(512,000 \pm 40,000$, mean \pm SEM, $n=27$ ), the rates of peptide hydrolysis were expressed as nanomoles of substrate hydrolyzed (or product produced) per minute per well of confluent cells.

HPLC analysis. A high performance liquid chromatograph system (two model 6000A pumps, a model 730 Data Module, a model 721 System Controller, a model 710B WISP Autosampler, and a LambdaMax Model 481 LC Spectrophotometer [set at $210 \mathrm{~nm}$ ]; Waters Associates, Milford, MA) was employed for HPLC analysis. Kinin and enkephalin substrates and metabolites were separated and quantified as previously described $(32,33)$ on a reverse phase column $\left(10-\mu \mathrm{m}, \mathrm{C}_{18^{-}}\right.$ $\mu$ Bondapak, $1.9 \times 30 \mathrm{~cm}$; VYDAC, Hesperia, CA) at a constant flow rate of $2 \mathrm{ml} / \mathrm{min}$ using a linear gradient from $100 \%$ solvent $A$ to $35 \%$ solvent $\mathrm{A} / 65 \%$ solvent $\mathrm{B}(21 \mathrm{~min})$, followed by column reequilibration in solvent A ( $3 \mathrm{~min})$. Solvent A was $0.05 \%$ trifluoroacetic acid ( $\mathrm{vol} / \mathrm{vol}$ ) in triple distilled water and solvent B was $0.04 \%$ trifluoroacetic acid ( $\mathrm{vol} / \mathrm{vol}$ ) in acetonitrile. Substance $P$ and substance $P$ metabolites were separated and quantified (34) (System II) with the abovenoted column at a constant flow rate of $2 \mathrm{ml} / \mathrm{min}$ and a linear gradient from $80 \%$ solvent $A / 20 \%$ solvent B to $40 \%$ solvent $A / 60 \%$ solvent B ( $25 \mathrm{~min}$ ) followed by column reequilibration $(5 \mathrm{~min}$ ). Solvent $A$ was $0.5 \mathrm{M}$ phosphoric acid, buffered to $\mathrm{pH} 2.5$ with triethylamine and solvent B was acetonitrile. For both systems, integration of sample peak areas and quantification of peptide substrates and metabolites against the last-run standards (run every sixth injection) were automatically calculated by the data module.

Synthetic substrate hydrolysis by homogenates of synovial cells. For preparation of synovial cell homogenates, cells were grown to con- 
A

CONTROL

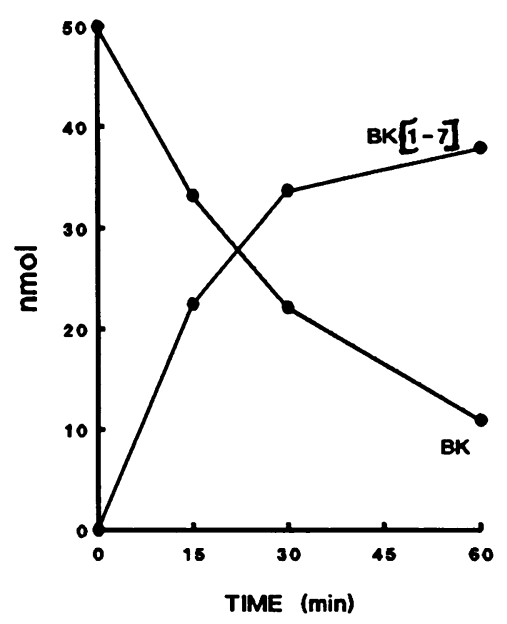

B

PHOSPHORAMIDON

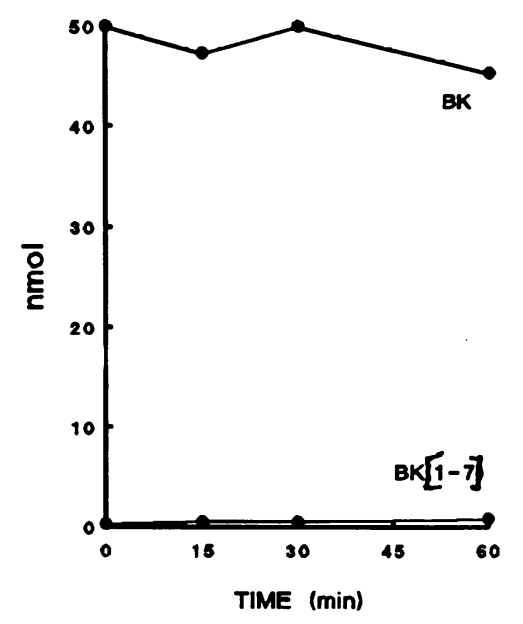

Figure 1. Metabolism of bradykinin by intact synovial cells. Confluent wells of cells were exposed to bradykinin ( $50 \mathrm{nmol}$ ) in the absence (CONTROL) or presence of phosphoramidon $(10 \mu \mathrm{M})$. Aliquots were removed at varying times and analyzed for the amount of intact peptide $(B K)$ or bradykinin [1-7] $(B K[1-7])$. Each point represents a single measurement from a representative experiment. fluence in $75-\mathrm{cm}^{2}$ flasks. Cells were washed twice and then scraped in $10 \mathrm{ml}$ of PGCM buffer. The cell suspension was centrifuged at 1,200 $\mathrm{rpm}$ for $8 \mathrm{~min}$ and the supernatant discarded. Cells were resuspended in $2 \mathrm{ml}$ of $0.1 \mathrm{M}$ Tris buffer, $\mathrm{pH} \mathrm{7.4;} \mathrm{broken} \mathrm{by} \mathrm{sonication} \mathrm{and} \mathrm{freeze}$ thawing; and assayed for synthetic substrate hydrolysis. Aminopeptidase A (AmA) (EC 3.4.11.7), AmM (EC 3.4.11.2), DAP IV (EC 3.4.14.5), and NEP-24.11 (EC 3.4.24.11) activities were determined fluorometrically by hydrolysis of the synthetic substrates, $\alpha$-glutamylnaphthylamide (AmA), alanyl-, leucyl- and arginyl-naphthylamide (AmM), glycyl-prolyl-naphthylamide (DAP IV), and dansyl-D-AlaGly-pNO ${ }_{2}$-Phe-Gly (NEP), as previously described (35-38). Reaction specificity was established by inhibition with appropriate inhibitors, including amastatin (AmM), diprotin A (DAP IV) (39), phosphoramidon, and ZINCOV (NEP-24.11) (40).

Immunoelectrophoresis. Immunoelectrophoresis (electroimmunoassay) of solubilized ( $2 \%$ Triton X-100) synovial cell homogenate and purified AmM against antisera to human AmM was carried out in $1.0-\mathrm{mm}$ thick $1 \%(\mathrm{wt} / \mathrm{vol}$ ) agarose gel containing $1 \%$ ( vol / vol) Triton $\mathrm{X}-100$ as previously described $(35,41)$. Samples were vertically electrophoresed $(1.5 \mathrm{~V} / \mathrm{cm}$ for $15 \mathrm{~h})$ directly into antisera-containing gel. After repeated dehydration/hydration of the gel to remove soluble protein, the AmM immunoprecipitin line was stained using alanyl-4methoxy-2-naphthylamide. Peak area measurements were determined using Sigma Scan (Jandel Scientific, Corte Madera, CA).

Flow cytometry analysis. Cells were grown to confluence in 100$\mathrm{mm}$ culture dishes and lifted by vigorous pipeting in PBS containing 1-6 mM EGTA for $5 \mathrm{~min}$. $3 \times 10^{5}$ cells were suspended in 40- $\mu 1$ aliquots of PBS $/ 0.2 \%$ BSA (pH 7.4) containing the desired $\mathrm{mAb}$ and 4 $\mathrm{mg} / \mathrm{ml}$ of human $\mathrm{IgG}$ (to block Fc receptors) for $30 \mathrm{~min}$ at $4^{\circ} \mathrm{C}$ as previously described (42). The cells were washed, resuspended in saturating amounts of phycoerythrin-conjugated goat $\mathrm{F}\left(\mathrm{ab}^{\prime}\right)_{2}$ anti-mouse IgG antibody (Tago, Inc., Burlingame, CA) for an additional $30 \mathrm{~min}$, and then washed again. Fluorescence was measured using a flow cytometer (EPICS Profile; Coulter Electronics Inc., Hialeah, FL) and was expressed as mean fluorescence intensity. The percentage of cells staining positively with each $\mathrm{mAb}$ was calculated by comparison to background staining observed using an irrelevant mouse $\mathrm{IgG}_{1} \mathrm{mAb}$.

\section{Results}

We adopted two approaches to identify and characterize putative peptide degrading enzymes in the membranes of human synovial cells from RA and OA patients. In the first, we sought to define the potential spectrum of synovial cell peptidases in- volved in the metabolism of kinins and substance $\mathrm{P}$ by measuring in intact cells the effect of specific enzyme inhibitors on the rate of degradation of parent peptide as well as on the rate and identity of metabolite(s) generated. Secondly, we confirmed the identity of each of the peptidases by measuring the hydrolysis of selective synthetic substrates by synovial cell homogenates and by immunological identification of protein on intact cells and in homogenates.

\section{Peptide metabolism by intact human synovial cells}

Kinin metabolism. Exposure of bradykinin to intact synovial cells resulted in rapid and progressive degradation, as evidenced by the loss in the supernatant of $50 \%$ of intact peptide within $30 \mathrm{~min}$ and concomitant production of bradykinin [1-7] (Fig. $1 A$ ) and Phe-Arg (not shown). No des ( $\left.\operatorname{Arg}^{9}\right)$ bradykinin production was observed, even in the presence of $\mathrm{CoCl}_{2}$, which enhances CPN activity, and inhibition of CPN (MERGEPTA; $10 \mu \mathrm{M}$ ) had no effect on degradation of bradykinin (not shown). Similarly, inhibition of angiotensin-converting enzyme (ACE) with captopril ( $10 \mu \mathrm{M})$ was without effect. Hydrolysis was nearly completely inhibited, however, by the NEP24.11 inhibitor, phosphoramidon (Fig. $1 B$ ). Thus, in all of the seven synovial cell lines examined, NEP-24.11 accounted for essentially all observed degradation of bradykinin $(1.39 \pm 0.29$ $\mathrm{nmol} / \mathrm{min}$ per well; Table I), and when analyzed separately rates in RA- $(1.44 \pm 0.52 \mathrm{nmol} / \mathrm{min}$ per well; $n=3)$ and OA $(1.35 \pm 0.41 \mathrm{nmol} / \mathrm{min}$ per well; $n=4)$-derived cells were similar ( $P$ value NS, Student's $t$ test).

Exposure of lysylbradykinin to synovial cells resulted in the rapid but transient appearance of bradykinin, followed by the appearance of the metabolites bradykinin [1-7] and Phe-Arg (not shown). As expected, phosphoramidon inhibited the formation of the latter two metabolites, confirming the role of NEP-24.11 $(0.80 \pm 0.19 \mathrm{nmol} / \mathrm{min}$ per well; Table I) in the metabolism of lysylbradykinin. Interestingly, in the presence of phosphoramidon, rapid conversion of lysylbradykinin to bradykinin was observed $(3.74 \pm 0.46 \mathrm{nmol} / \mathrm{min}$ per well; Table I), demonstrating the presence of an aminopeptidase on synovial cells. That this conversion was due to AmM was suggested by the ability of the AmM inhibitor amastatin to completely inhibit production of bradykinin (Fig. 2). Further confirma- 
Table I. Peptide Hydrolysis by Intact Synovial Cells*

\begin{tabular}{lcccc}
\hline \multicolumn{1}{c}{ Peptide } & AmM & NEP-24.11 & DAP IV & Unknown \\
Bradykinin & 0 & $\begin{array}{c}1.39 \pm 0.29 \\
(n=7)\end{array}$ & 0 & $<0.2$ \\
Lysylbradykinin & $\begin{array}{c}3.74 \pm 0.46 \\
(n=7)\end{array}$ & $\begin{array}{c}0.80 \pm 0.19 \\
(n=5)\end{array}$ & 0 & $<0.2$ \\
[Leu' ${ }^{5}$ ]enkephalin & $\begin{array}{c}2.44 \pm 0.33 \\
(n=5) \\
\text { Substance P }\end{array}$ & $\begin{array}{c}1.30 \pm 0.45 \\
(n=5)\end{array}$ & 0 & $<0.2$ \\
& 0 & $\begin{array}{c}0.93 \pm 0.15 \\
(n=6)\end{array}$ & $\begin{array}{c}0.84 \pm 0.18 \\
(n=9)\end{array}$ & $<0.2$ \\
& & &
\end{tabular}

* Wells of confluent cells from RA and OA patients were exposed to peptide $(50 \mu \mathrm{M})$ in the presence or absence of specific peptidase inhibitors for varying times and the amount of intact peptide remaining and/or metabolite generated was quantified by HPLC (as described in Methods). Enzyme activities represent mean \pm SEM of individual or duplicate measurements from experiments in $n=5-9$ different cell lines.

tion of this enzyme as AmM, rather than one of several related aminopeptidases, was indicated by the absence of significant hydrolysis of bradykinin product, a feature consistent with the inability of AmM to hydrolyze $\mathrm{NH}_{2}$-terminal Arg-Pro bonds $(33,35)$. The same pattern of metabolism of lysylbradykinin by NEP-24.11 and AmM was observed in the five cell lines studied and the relative rates of each enzyme were similar in RA (NEP-24.11, 0.56 \pm 0.17 ; AmM 3.09 $\pm 0.42 \mathrm{nmol} / \mathrm{min}$ per well; $n=3$ ) and OA (NEP-24.11, 1.16 $\pm 0.26, n=2$; AmM $4.22 \pm 0.68 \mathrm{nmol} / \mathrm{min}$ per well, $n=4)$ derived cell lines $(P$ value NS, Student's $t$ test).

Enkephalin metabolism. The opioid peptides, enkephalins, are also potential substrates for NEP-24.11 (also known as "enkephalinase") and AmM $(35,43)$. In view of the potent apparent NEP-24.11 and AmM activities on synovial cells and recent suggestions that endogenous opiods may play a role in analgesia in the inflamed joint, we also examined the ability of synovial cells to degrade [ Leu $^{5}$ ] enkephalin. As shown in Fig. 3 $A$, [ Leu $^{5}$ ] enkephalin was rapidly hydrolyzed ( $50 \%$ hydrolysis within $10 \mathrm{~min}$ ) to the AmM metabolite, des-Tyr ${ }^{1}$-enkephalin and the NEP-24.11 metabolite, Tyr-Gly-Gly. Inhibition of NEP-24.11 with phosphoramidon prevented the generation of Tyr-Gly-Gly, but did not stop the hydrolysis of [ $\left.\mathrm{Leu}^{5}\right]-$ enkephalin by AmM $(2.44 \pm 0.33 \mathrm{nmol} / \mathrm{min}$ per well $)$, as evidenced by the production of des-Tyr ${ }^{1}$-enkephalin (Fig. $3 B$ ). In turn, inhibition of AmM with amastatin stopped the formation of des-Tyr ${ }^{1}$-enkephalin but did not stop degradation of [ $\mathrm{Leu}^{5}$ ]enkephalin by NEP-24.11 (1.30 $\pm 0.45 \mathrm{nmol} / \mathrm{min}$ per well $)$, as evidenced by the continued generation of the Tyr-Gly-Gly metabolite (Fig. $3 C$ ). Nearly complete inhibition of enkephalin degradation was achieved only by simultaneous inhibition of both AmM and NEP-24.11 (Fig. $3 \mathrm{D}$ ). Thus, synovial cell-associated AmM and NEP-24.11 both metabolize enkephalin, although the predominant activity is due to AmM (Table I). This pattern is maintained when RA- (NEP-24.11, 1.40 \pm 0.75 ; AmM, 2.74 $\pm 0.47 \mathrm{nmol} / \mathrm{min}$ per well; $n=3$ ) and OA (NEP$24.11,1.13 \pm 0.55 ; \mathrm{AmM}, 2.00 \pm 0.30 \mathrm{nmol} / \mathrm{min}$ per well; $n$ $=2$ )-derived cells are considered separately ( $P$ values NS).

Substance $P$ metabolism. Like the other peptides, substance $\mathbf{P}$ was rapidly degraded upon exposure to synovial cells, with $50 \%$ hydrolysis occurring within $30 \mathrm{~min}$ (Fig. 4). However, in contrast to the results obtained for bradykinin, the NEP-24.11 inhibitor phosphoramidon only partially inhibited metabolism of the peptide. The DAP IV inhibitor diprotin A (39) also partially inhibited hydrolysis, while the combination of phosphoramidon and diprotin A nearly completely inhibited degradation of substance $P$ (Fig. 4). These data are consistent with the known ability of DAP IV to hydrolyze substance $P$ (34) and demonstrate that degradation of substance $P$ by synovial cells is due to the combined actions of NEP-24.11 and DAP IV ( Table I). This pattern of substance P degradation, as well as the relative enzyme rates, were similar in RA- (NEP$24.11,0.96 \pm 0.32$; DAP IV, $0.50 \pm 0.34 \mathrm{nmol} / \mathrm{min}$ per well; $n$ $=3$ ) and OA (NEP-24.11, 0.90 \pm 0.11 ; DAP IV, $1.01 \pm 0.20$ $\mathrm{nmol} / \mathrm{min}$ per well; $n=3-6)$-derived cells ( $P$ values NS, Student's $t$ test).
PHOSPHORAMIDON

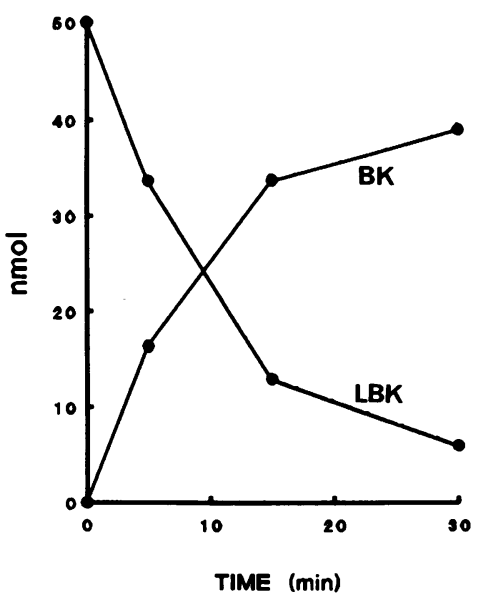

PHOS/AMASTATIN

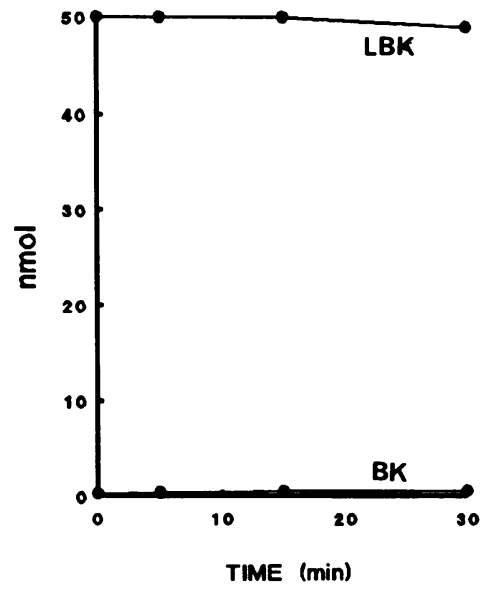

Figure 2. Metabolism of lysylbradykinin by intact synovial cells. Confluent wells of cells were exposed to lysylbradykinin ( $50 \mathrm{nmol}$ ) in the presence of phosphoramidon $(10 \mu \mathrm{M})$ alone or phosphoramidon and amastatin together ( $10 \mu \mathrm{M}$ each $)$. Aliquots were removed at varying times and analyzed for the amount of lysylbradykinin $(L B K)$ or bradykinin $(B K)$. Each point represents a single measurement from a representative experiment. 


\section{B PHOSPHORAMIDON}
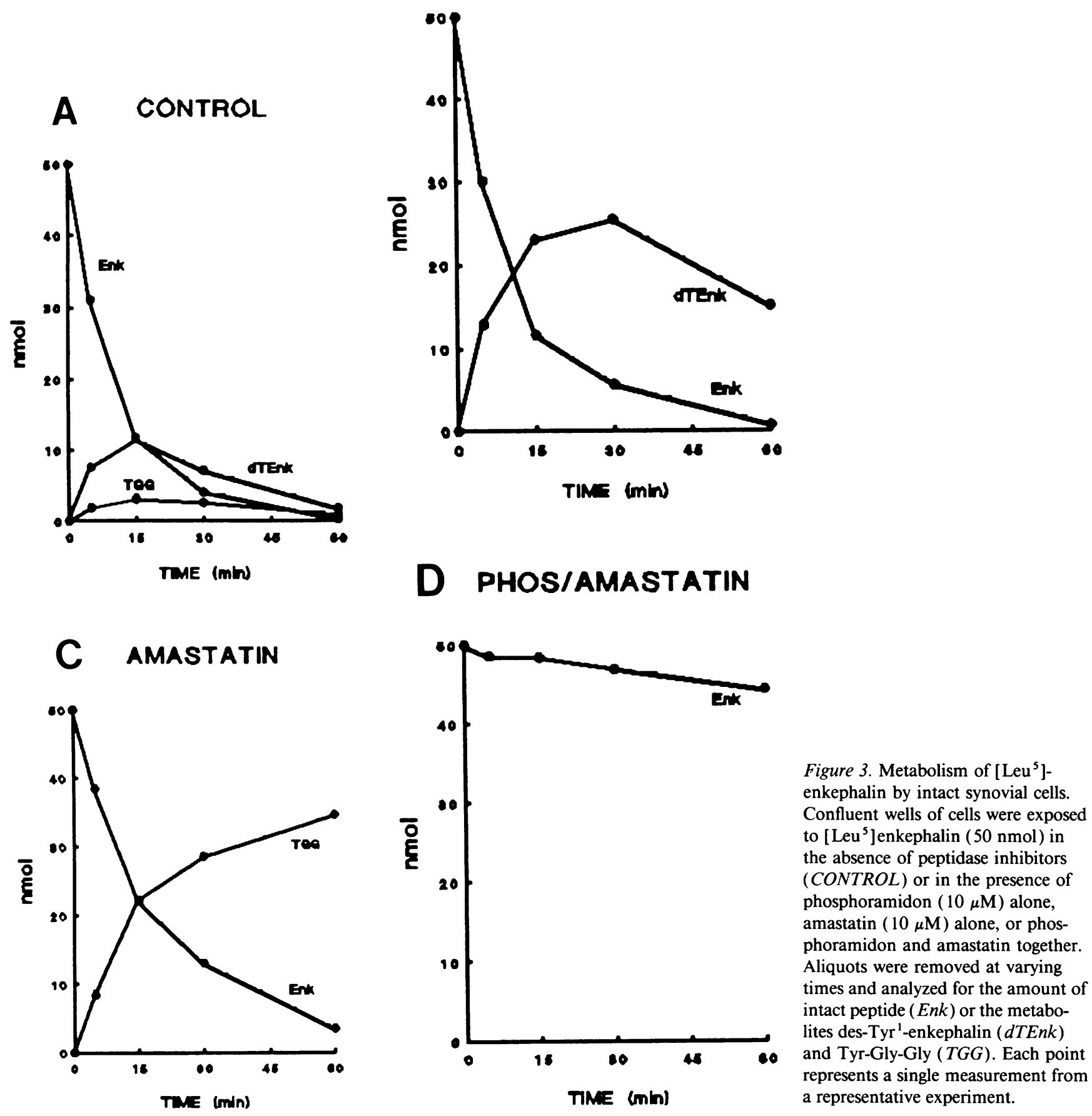

Metabolism of synthetic substrates by homogenates of human synovial cells

Homogenates of human synovial cells exhibited no significant AmA-like $\alpha$-glutamyl-naphthylamidase activity (not shown). However, as shown in Table II, significant alanyl-naphthylamidase activity was present $(442 \pm 84 \mathrm{nmol} / \mathrm{min} \cdot \mathrm{ml})$, and the ratio of the rates of hydrolysis of alanyl-, leucyl-, and arginylnaphthylamides (100:50:22) was comparable to that obtained with purified human AmM (not shown). Consistent with the biochemical characteristics of purified AmM (35), the alanylnaphthylamidase activity of the synovial cell lysate was more sensitive to inhibition by amastatin $\left(\mathrm{IC}_{50}=100 \mathrm{nM}\right)$ than bestatin $\left(\mathrm{IC}_{50}=5 \mu \mathrm{M}\right)$ or puromycin $\left(\mathrm{IC}_{50}=30 \mu \mathrm{M}\right)$, was completely inhibited by $o$-phenanthroline $(1 \mathrm{mM})$, and was unaffected by inhibitors of ACE (captopril), CPN (MERGEPTA), NEP-24.11 (phosphoramidon), and DAP IV (diprotin A) $(<12 \%$ inhibition at a final concentration of $100 \mu \mathrm{M})$.

Quantitative rocket immunoelectrophoresis (electroim- 


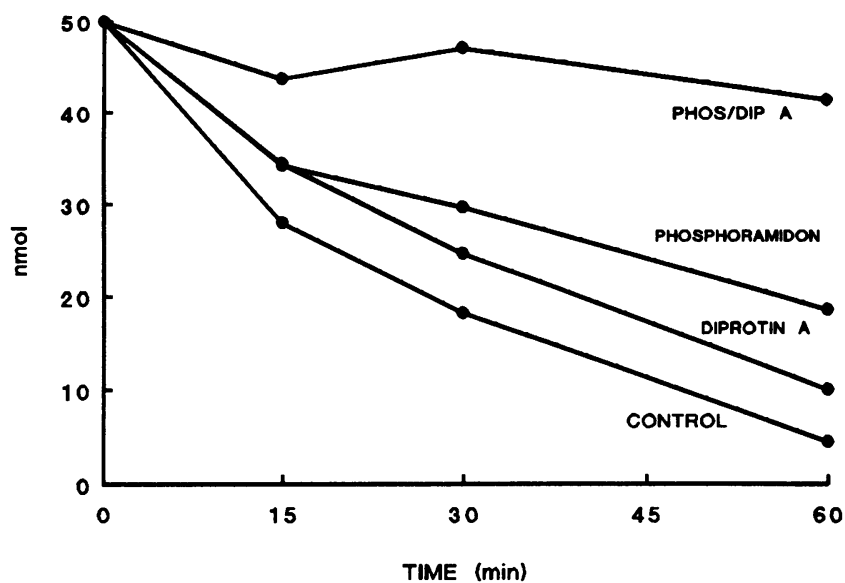

Figure 4. Metabolism of substance $\mathrm{P}$ by intact synovial cells. Confluent wells of cells were exposed to substance $P(50 \mathrm{nmol})$ in the absence of peptidase inhibitors, in the presence of phosphoramidon $(10 \mu \mathrm{M})$ or diprotin $\mathrm{A}(10 \mu \mathrm{M})$ alone, or in the presence of phosphoramidon and diprotin $\mathrm{A}(10 \mu \mathrm{M}$ each $)$. Aliquots were removed at varying times and analyzed for the amount of intact peptide. Each point represents a single measurement from a representative experiment.

munoassay) of pure human AmM and detergent-solubilized synovial cell homogenate produced rocket-shaped precipitates with peak areas proportionate to the amount of sample used (Fig. 5). When peak areas of immunoreactive AmM ([iAmM]) were plotted against the units of alanyl-naphthylamidase activity inoculated onto the gels, the relationships of [iAmM] to alanyl-naphthylamidase activity were similar for both purified AmM and synovial cell homogenates.

NEP-24.11 and DAP IV activities were also confirmed in synovial cell homogenates (Table II). NEP-24.11 activity $\left(14.3 \pm 1.4 \mathrm{nmol} / \mathrm{min} \cdot \mathrm{ml}\right.$; dansyl-D-Ala-Gly-pNO${ }_{2}-\mathrm{Phe}-\mathrm{Gly}$ hydrolysis) was specifically inhibited by phosphoramidon $\left(\mathrm{IC}_{50}=1.5 \mu \mathrm{M}\right)$ and ZINCOV $\left(\mathrm{IC}_{50}=7 \mu \mathrm{M}\right)$. Similarly, DAP IV activity $(128 \pm 11 \mathrm{nmol} / \mathrm{min} \cdot \mathrm{ml}$; glycyl-prolyl-naphthylam-

Table II. Hydrolysis of Synthetic Substrates by Synovial Cell Homogenates*

\begin{tabular}{lcc}
\hline \multicolumn{1}{c}{ Enzyme } & \multicolumn{1}{c}{ Substrate } & Activity \\
\hline Aminopeptidase M & Ala-naphthylamide & $\mathrm{nmol} / \mathrm{min} \cdot \mathrm{ml}$ \\
& & $\begin{array}{l}442 \pm 84 \\
(n=7)\end{array}$ \\
& Leu-naphthylamide & $\begin{array}{l}221 \pm 65 \\
(n=3)\end{array}$ \\
& & 101 \\
& Arg-naphthylamide & $(n=2)$ \\
Neutral & & $14.3 \pm 1.4$ \\
endopeptidase-24.11 & dansyl-D-Ala-Gly-pNO $2^{-}$ & $(n=10)$ \\
Dipeptidyl & Phe-Gly & $128 \pm 11$ \\
(amino)-peptidase IV & Gly-Pro-naphthylamide & $(n=7)$ \\
& &
\end{tabular}

* Synovial cell homogenates were prepared from flasks of confluent cells as described in Methods. Enzyme activities represent the mean \pm SEM of replicate measurements $(n)$ from two separate OA-derived cell lines.

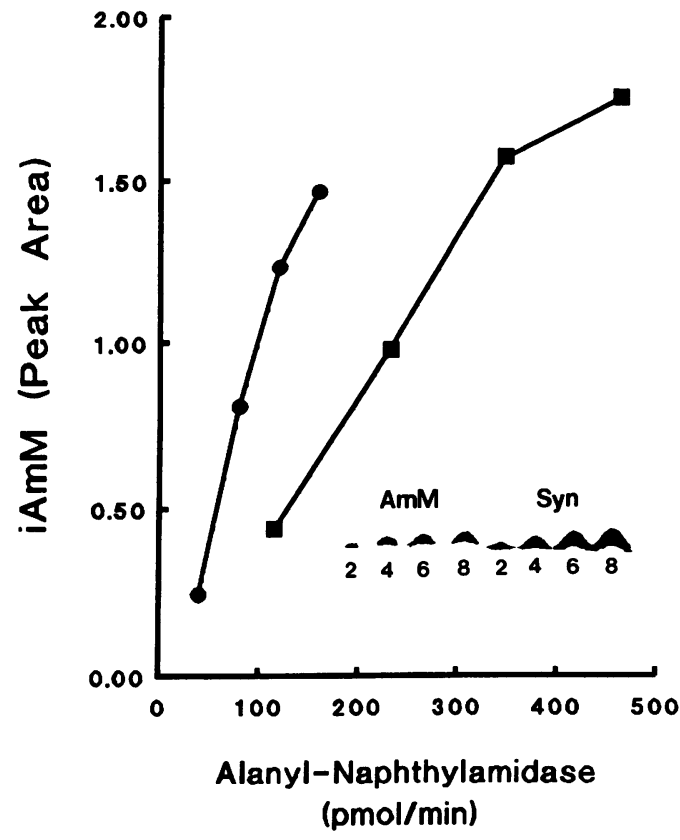

Figure 5. Correlation of amount of immunoreactive AmM with alanyl-naphthylamidase activity by purified AmM $(\bullet)$ and synovial cell homogenate $(\bullet)$. The units of alanyl-naphthylamidase activity (pmol/min) are plotted against the peak area of immunoreactive $\mathrm{AmM}$, as measured by quantitative rocket immunoelectrophoresis. Inset demonstrates AmM immunoprecipitin peaks from varying amounts (2-8 $\mu \mathrm{l})$ of purified AmM and synovial cell homogenate.

ide hydrolysis) was specifically inhibited by diprotin $\mathrm{A}\left(\mathrm{IC}_{50}\right.$ $=9 \mu \mathrm{M})$.

\section{Flow cytometric identification of peptidases}

The membrane antigens, CD10/CALLA, CD13, and CD26, previously described on select populations of hematopoietic cells, have only recently been identified as NEP-24.11, AmM, and DAP IV, respectively (44). This recognition enabled us to use mAbs and flow cytometric analysis to further confirm the expression of these enzymes on synovial cells. As shown in Fig. 6, all three antigens, CD10, CD13, and CD26, were consistently expressed in both RA- and OA-derived cells. Furthermore, both the percentage of positive cells and the fluorescence intensities for each antigen were similar in RA- and OA-derived cell lines (Table III). In addition, in one RA cell line studied, expression of all three antigens, CD10, CD13, and CD26, persisted during repeated passaging (Table IV).

\section{Discussion}

These studies provide the first direct evidence of the presence of three membrane-associated peptidases on human synovial cells. Although plasma-derived CPN activity has been demonstrated in synovial fluid $(4,45)$, few investigations have focused on the potential capability of the synovium itself to degrade peptides. Several early studies demonstrated kinin degrading and aminopeptidase activities in homogenates of human synovial tissue; however, definitive identification of the enzyme activities was not made $(4,22,23)$. More recently, NEP-24.11 (24) and DAP IV (25) activities have been identi- 


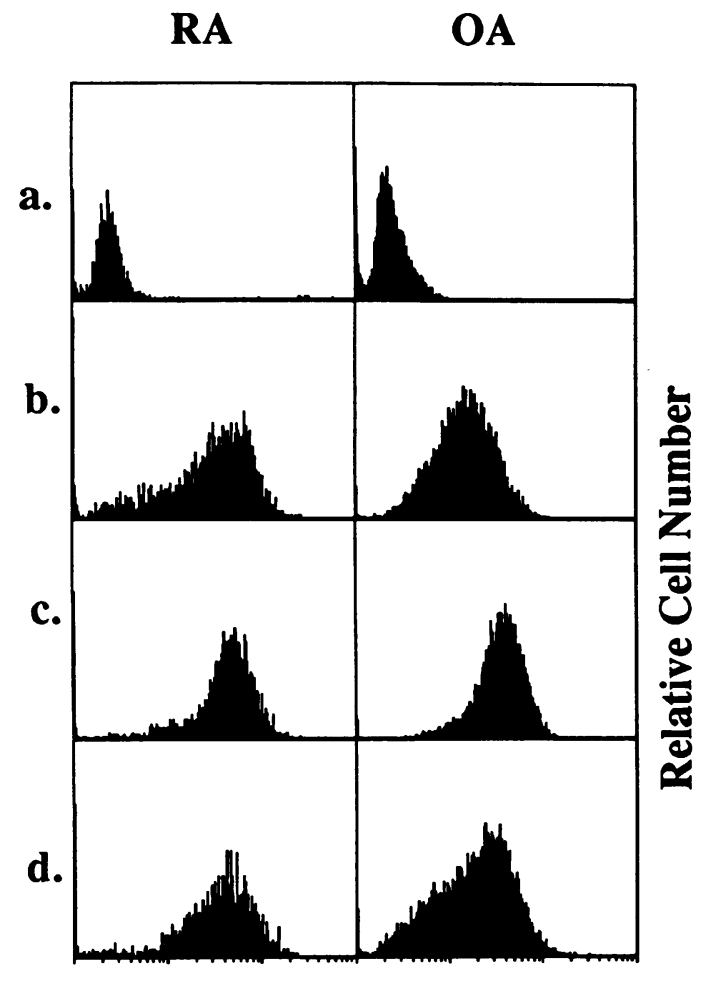

\section{Fluorescence Intensity}

Figure 6. Expression of CD10, CD13, and CD26 on human synovial cells. Representative histograms from synovial cells obtained from one RA and one OA patient stained with mAbs recognizing $(a)$ control ( $\left.\mathrm{IgG}_{1}\right),(b) \mathrm{CD} 10$ (J5), (c) CD13 (MY7), and (d) CD26 (Ta1).

fied in sonicates of human synovial tissue, but the cellular source of the activities was not identified. Werb and Clark (46) demonstrated NEP-24.11 expression on rabbit synovial fibroblasts, but its contribution, relative to that of other potentially colocalizing peptidases, to the metabolism of physiologically relevant peptides was not characterized.

The synovium of normal joints is a thin, delicate structure, the lining (intimal) layer of which is only one to three cells thick and is composed primarily of fibroblast-like and macro-

Table III. Expression of CD10, CD13, and CD26 on Synovial Cells

\begin{tabular}{|c|c|c|c|c|c|c|}
\hline \multirow[b]{2}{*}{$C D$} & \multirow{2}{*}{$\begin{array}{l}\text { Antigen } \\
\text { specificity }\end{array}$} & \multirow[b]{2}{*}{$\mathrm{mAb}$} & \multicolumn{2}{|c|}{$\mathrm{RA}(n=3)$} & \multicolumn{2}{|c|}{$\mathrm{OA}(n=3)$} \\
\hline & & & Percent* & MFI & Percent* & MFI \\
\hline CD10 & NEP-24.11 & J5 & $93.3 \pm 2.6$ & $33.1 \pm 4.8$ & $94.3 \pm 3.4$ & $34.2 \pm 9.7$ \\
\hline $\mathrm{CD} 13$ & $\mathrm{AmM}$ & MY7. & $97.5 \pm 1.3$ & $48.0 \pm 1.6$ & $98.8 \pm 0.2$ & $53.0 \pm 8.2$ \\
\hline CD26 & DAP IV & Tal & $95.3 \pm 1.8$ & $34.4 \pm 4.3$ & $93.9 \pm 4.8$ & $35.8 \pm 8.9$ \\
\hline
\end{tabular}

\footnotetext{
* Values represent the percent of synovial cells staining positively for each antigen (mean \pm SEM). The mean fluorescence intensity (MFI) values are expressed in a logarithmic scale (mean \pm SEM). MFI values in the presence of control IgG1 were 2.4 and 3.2 for RA and OA cells, respectively. Neither the percentage of cells expressing each of the three antigens nor their MFI values was statistically significantly different when RA and OA cells were compared $(P=\mathrm{NS}$, Student's $t$ test).
}

Table IV. Effect of Passaging on Expression of CD10, CD13, and $C D 26$

\begin{tabular}{|c|c|c|c|c|c|c|}
\hline \multirow{2}{*}{$\begin{array}{l}\text { Passage } \\
\text { number }\end{array}$} & \multicolumn{2}{|c|}{ CD10/NEP-24.11 } & \multicolumn{2}{|c|}{$\mathrm{CD} 13 / \mathrm{AmM}$} & \multicolumn{2}{|c|}{ CD26/DAP IV } \\
\hline & Percent* & MCF & Percent ${ }^{*}$ & MFI & Percent $*$ & MFI \\
\hline 1 & 88.6 & 41.6 & 95.2 & 48.9 & 92.0 & 41.6 \\
\hline 3 & 97.6 & 28.0 & 99.5 & 36.2 & 98.3 & 27.7 \\
\hline 5 & 91.3 & 57.1 & 96.3 & 76.1 & 94.2 & 64.6 \\
\hline
\end{tabular}

* Values represent the percent of synovial cells from one RA cell line that stained positively for each antigen at successive passages. The mean fluorescence intensity (MFI) values are expressed in a logarithmic scale.

phage-like cells. In contrast, the rheumatoid synovial lining is greatly hypertrophied and a marked increase in the number of both cell populations is observed (26). That the fibroblastic population of cells plays an important role in the maintenance of normal joint function is suggested by its elaboration of joint lubricants such as hyaluronic acid (26). In addition, the fibroblast appears to play a key role in the destruction of the rheumatoid joint, as evidenced by its potent capacity in vitro to secrete prostaglandins and matrix-degrading proteases, including collagenase, stromelysin, and gelatinases, in response to soluble products of mononuclear cells such as IL-1 (31, 47, 48). We hypothesized that the fibroblastic synovial cell may also be a potent source of peptide-degrading activity in the joint, and this concept was supported by previous observations in which bradykinin was rapidly degraded by these cells in vitro (7). Through the use of specific peptidase inhibitors, the identification of specific peptide metabolites, and the use of selective synthetic substrates and/or antisera, we have demonstrated the presence of three specific peptidases (NEP-24.11, AmM, and DAP IV) colocalizing on human synovial fibroblasts. Furthermore, the use of intact rather than broken cells for these studies permitted the localization of these peptidases to the cell surface, suggesting that neither internalization of peptide nor secretion of enzyme is necessary for peptide metabolism by synovial cells. Finally, we have shown a selective pattern of metabolism for each of the peptides examined and have found that RA- and OA-derived fibroblasts are indistinguishable with regard to relative expression and rates of their peptidase activities.

The metabolism of bradykinin in plasma and vasculature is mediated primarily by $\mathrm{ACE}, \mathrm{CPN}$, and CPN-like enzymes (20). In contrast, no ACE, CPN, or CPN-like activities were found in synovial cells. This observation was confirmed by the inability of MERGEPTA and captopril to decrease, or $\mathrm{CoCl}_{2}$ to enhance, the rate of bradykinin degradation by synovial cells. It indicates further that adequate removal of serum-containing culture medium was achieved in these studies and that none of the peptidase activities identified in synovial cells could, therefore, be attributed to contamination from calf serum. In fact, the cell surface peptidase NEP-24.11 was responsible for metabolism of bradykinin via hydrolysis of the $\mathrm{Pro}^{7}-\mathrm{Phe}^{8}$ bond to produce the inactive metabolites, BK[1-7] and Phe-Arg (which were subject to further hydrolysis with continued incubation ). That degradation of bradykinin was completely due to NEP-24.11 was confirmed by the ability of phosphoramidon to 
completely inhibit metabolism. The recent identification of the CD10/CALLA (common acute lymphoblastic leukemia-associated antigen ) as NEP-24.11 (49) enabled us, through the use of immunofluorescence flow cytometry, to further confirm the presence of this peptidase on the synovial cell surface.

No contribution to the degradation of bradykinin from the two other identified peptidases on synovial cells, AmM and DAP IV, would be expected (20). AmM hydrolyzes neutral and basic amino acids, except those involving X-Pro bonds, from the $\mathrm{NH}_{2}$ terminus of low molecular weight peptides and is thus incapable of hydrolyzing the $\mathrm{Arg}^{1}-\mathrm{Pro}^{2} \mathrm{NH}_{2}$ terminus of bradykinin $(32,35)$. DAP IV hydrolyzes $\mathrm{NH}_{2}$ terminal X-Pro dipeptides, except those involving Pro in the third position, and likewise is incapable of hydrolyzing the $\mathrm{Arg}^{1}-\mathrm{Pro}^{2}-\mathrm{Pro}^{3}$ $\mathrm{NH}_{2}$ terminus of bradykinin (50-52).

Lysylbradykinin was also metabolized by the synovial cell to biologically inactive metabolites, primarily through the action of NEP-24.11. However, when this enzyme was inhibited with phosphoramidon, conversion of lysylbradykinin to bradykinin was observed and was due to the action of AmM. Identification of the enzyme as AmM was suggested in intact cells by the ability of amastatin to completely inhibit the conversion of lysylbradykinin to bradykinin. Further confirmation was provided in studies of cell lysates in which the enzyme hydrolyzed alanyl-naphthylamide more rapidly than leucyl- and arginylnaphthylamides, was 50 -fold more sensitive to inhibition by amastatin than bestatin, was relatively resistant to puromycin, and was unaffected by captopril, MERGEPTA, phosphoramidon, and diprotin A. In addition, the ratio of alanyl-naphthylamidase activity to amount of immunoreactive $A m M$ found in synovial cell lysates was comparable to that for purified AmM. Collectively, these characteristics differentiate AmM from ACE, CPN, NEP-24.11, DAP IV, and from other neutral/basic amino acid selective aminopeptidases, including leucine aminopeptidase (EC 3.4.11.1) and aminopeptidase B (EC 3.4.11.6) $(35,37)$. Final confirmation of the presence of this exopeptidase on synovial cells was provided by immunofluorescent staining with an mAb to the leukocyte antigen CD13 that has recently been identified as AmM/AmN (53).

The impressive ability of relatively small numbers of synovial fibroblasts in vitro to degrade nanomole amounts of kinins within minutes, coupled with their high level of CD10 antigen expression, are indicative of a large amount of NEP-24.11 on the membranes of these cells. This observation has several potential clinical implications. The presence and amount of NEP24.11 may explain in part the relative insensitivity of untreated human synovial fibroblasts to bradykinin (7) despite $\mathbf{B}_{2}$ kinin receptors that number $\sim 36,000$ sites per cell (54). In addition, the recent demonstration of measurable NEP-24.11 activity in synovial fluids (55) suggests that the synovial fibroblast, in addition to expressing NEP-24.11 on its cell surface, may also have the capacity to secrete this enzyme into the joint cavity. The similar intensity of NEP-24.11 expression on cells from OA and RA joints suggests that the potent ability of synovial fibroblasts to degrade kinins is not disease specific but rather may constitute a normal physiological function for these synovial lining cells. The synovial lining is in a strategic position to perform this function since it not only is in direct contiguity to the joint cavity, where bradykinin may be generated spontaneously (56), but in addition would be expected to en- counter kinins diffusing in from synovial vasculature. Since our data show that, cell per cell in vitro, RA- and OA-derived fibroblasts exhibit equivalent expression of NEP-24.11, it is likely in vivo that the intensely cellular RA synovium would exhibit increased expression of NEP-24.11 activity compared with the relatively hypocellular normal and OA synovia. In support of this concept, Sreedharan et al. (24) have demonstrated increased NEP-24.11 activity in sonicates of RA synovium compared with those of OA or traumatic origin, although the cell source was not identified. Furthermore, precedent for enhanced peptidase activity (NEP-24.11) in conjunction with cell growth exists in transformed human tracheal epithelial cells (57).

The ability of synovial cells to convert lysylbradykinin to bradykinin through the action of AmM, although also quite substantial, is of uncertain physiological significance. Although kallikrein-like activity in human synovial fluid and tissues has been demonstrated, controversy persists as to whether the predominant activity is of plasma (which would generate bradykinin) or of tissue (which would generate lysylbradykinin) origin $(58,59)$. Furthermore, changes in the relative ratio of lysylbradykinin to bradykinin over time would be unlikely to influence tissue responses since the two peptides exhibit equivalent affinities for the $B_{2}$ kinin receptor and, consequently, equivalent potencies in inducing physiological effects in most systems studied (20). Thus, although AmM catalyzes the conversion of lysylbradykinin to bradykinin, NEP-24.11 is the enzyme responsible for the biological inactivation of both kinins.

AmM clearly participates in the metabolism of a variety of other small peptides, however, including the low molecular weight opioid peptides known as "enkephalins" $(19,60,61)$. Although the role of opioids in endogenous pain control of arthritic animals has been examined primarily in brain and spinal cord tissues, recent data suggest that peripheral opioid receptors exist $(62,63)$ and mediate local analgesic responses (64) in articular and periarticular structures, and immunohistochemical studies have documented the presence of enkephalins in synovial tissues $(9,63)$. Furthermore, opioids may alter inflammatory processes by inhibiting the release of vasodilatory neurotransmitters from sensory nerve terminals (65) and by modulating immune cell responses such as chemotaxis, proliferation, and cytotoxicity (66-68).

We evaluated, therefore, the ability of the synovial fibroblast to metabolize [ $\mathrm{Leu}^{5}$ ]-enkephalin and the potential role that AmM might play in this process. NEP-24.11 has often been referred to as enkephalinase due to its ability to hydrolyze the Gly ${ }^{3}-\mathrm{Phe}^{4}$ bond of [ $\left.\mathrm{Leu}^{5}\right]-$ and [ $\mathrm{Met}^{5}$ ]enkephalin (43). Therefore, having already demonstrated NEP-24.11 activity on synovial cells, it was not surprising that phosphoramidon completely inhibited hydrolysis of [ $\left.\mathrm{Leu}^{5}\right]$ enkephalin to TyrGly-Gly. Of interest, however, was the observation that degradation of $\left[\mathrm{Leu}^{5}\right]$ enkephalin persisted at a quite rapid rate, in the presence of phosphoramidon, because of AmM-mediated hydrolysis of the $\mathrm{Tyr}^{1}$-Gly ${ }^{2}$ bond (des-Tyr ${ }^{1}$-enkephalin formation ). In fact, the rate of AmM-mediated hydrolysis of [ $\mathrm{Leu}^{5}$ ]enkephalin was faster $(2.44 \pm 0.33 \mathrm{nmol} / \mathrm{min}$ per well $)$ than that due to NEP-24.11 ( $1.30 \pm 0.45 \mathrm{nmol} / \mathrm{min}$ per well $)$. Thus, in contrast to the ability of phosphoramidon to completely inhibit bradykinin degradation, a combination of phosphoramidon and the AmM inhibitor amastatin was necessary to com- 
pletely inhibit synovial cell-mediated degradation of [ $\left.\mathrm{Leu}^{5}\right]-$ enkephalin. This dual processing of enkephalins by human synovial cells is in contrast to enkephalin metabolism in some central nervous system (CNS) sites where NEP-24.11 can predominate (69) and in plasma and vasculature where AmM predominates $(35,61,70)$. Collectively, these data illustrate that the potential physiological relevance of a peptide-degrading enzyme is determined not only by its biochemical specificity in vitro, but also by its anatomical location, local availability of substrate, and colocalization of enzymes competitively hydrolyzing the same peptides. Thus, two different peptides may be metabolized by the same enzyme in one location (e.g., bradykinin and enkephalin in synovium), whereas the same peptide may be metabolized by different enzymes in varying locations (e.g., enkephalin in the CNS, plasma, and synovium).

Although data supporting a role for opioid peptides in the modulation of articular pain and inflammation remain somewhat circumstantial, there is strong evidence as already discussed to support a role for another neuropeptide, substance $P$, in the inflammatory process in the joint. We evaluated, therefore, the ability of synovial fibroblasts to metabolize substance $\mathrm{P}$ and found its degradation, like that of kinins and enkephalin, to be very rapid and due in part to NEP-24.11 $(0.93 \pm 0.15$ $\mathrm{nmol} / \mathrm{min}$ per well). The latter finding was not surprising since substance $P$ is a recognized substrate for NEP-24.11 and we had already demonstrated expression of this enzyme on synovial cells. Of surprise, however, was the observation that degradation of substance $P$ proceeded at an equivalent rate even in the presence of the NEP-24.11 inhibitor phosphoramidon. This degradation was due to DAP IV $(0.84 \pm 0.18 \mathrm{nmol} /$ min per well), as evidenced by the ability of diprotin A to inhibit degradation. Thus, in contrast to kinin degradation by synovial fibroblasts, which is dependent exclusively upon NEP-24.11 activity, metabolism of the neuropeptides examined was mediated by two colocalizing but independent enzyme activities. The ability of NEP-24.11 to metabolize either exclusively or in conjunction with another peptidase all four substrates examined is consistent with its rather broad enzymatic specificity. The narrow specificity, on the other hand, of DAP IV for $\mathrm{NH}_{2}$-terminal X-Pro (except Pro-Pro) dipeptides is consistent with its ability to metabolize substance $\mathrm{P}$ but not kinins or [ $\mathrm{Leu}^{5}$ ] enkephalin. Thus, the presence of this enzyme on synovial cells may not have been recognized had substance $P$ metabolism not been examined. Further confirmation of the presence of DAP IV on synovial cell membranes was provided by immunofluorescent staining with an mAb to the leukocyte antigen CD26, which has recently been identified as DAP IV (71).

As with bradykinin, the potent capacity for synovial fibroblasts to degrade neuropeptides was not disease specific, as indicated by the similar rates of enzyme activities and corresponding antigen expression in RA- and OA-derived cells. These data suggest that regulation of intraarticular neuropeptide levels may also be a normal physiological function of the synovial lining and this function might also be expected to be enhanced in vivo in hypercellular, inflamed synovia. Indeed, several investigators have shown by immunohistochemical techniques a relative decrease in substance $P$ and/or enkephalin immunoreactivity in the synovia of patients with RA (9,
10 ) and rats with adjuvant arthritis (11) compared with normal and OA patients or normal rats. Although this decrease may be due in part to an unexplained decrease in number of nerve fibers themselves $(10,11)$, it is tempting to speculate that more vigorous metabolism of these peptides within the inflamed, hypercellular synovia may also have contributed to the decreased immunoreactivity.

Hypertrophy of the synovial lining has long been regarded as an unfavorable occurrence in the development of RA because of the presumed concomittant increase in the release of proinflammatory mediators such as proteolytic enzymes and prostanoids (72). Our data, however, in illustrating the ability of synovial fibroblasts to metabolize the proinflammatory peptides, kinins, and substance $P$, suggest a unique antiinflammatory function for the synovial lining that is likely to be enhanced with progressive hypertrophy of this lining. Paradoxically, enhanced degradation of opioids by synovial cell peptidases could promote intraarticular algesia but, as yet, data supporting a role for opioids in the modulation of pain and inflammation in the joint remain circumstantial.

The total amount of peptidase activity in synovia of inflamed versus noninflamed joints in vivo is unlikely to depend entirely on the relative numbers of fibroblastic cells, however. Macrophages, the other prominent cell type in synovial lining, may themselves express peptidase activity in a profile similar to or different from that of fibroblastic cells. Although we did not examine peptidase activity in purified populations of synovial macrophages, to our knowledge, only AmM, not NEP-24.11 or DAP IV, activity has been demonstrated on macrophages from other organs (44). Alternatively, soluble products of macrophages might influence the in vivo expression of peptidases on fibroblastic cells. We failed to observe a change in the immunofluorescent expression of NEP-24.11, AmM, or DAP IV on fibroblastic cells with progressive passaging and time in culture. Since the macrophage subpopulation of primary synovial cell cultures routinely disappears by the first or second passage (31), this observation suggests in fact that fibroblastic peptidase expression is not dependent upon the physical presence of macrophages or their soluble products. The failure of IL-1 treatment of synovial fibroblasts to alter the rates of NEP24.11-, AmM- and DAP IV-mediated kinin and neuropeptide degradation (unpublished observations) further supports this concept, although other macrophage-associated cytokines have not been examined.

The persistence over time in culture of, and lack of effect of IL-1 on, peptidase expression on synovial cells is in direct contrast to the expression of proteases, such as collagenase and stromelysin, by synovial cells, in that secreted levels are high in primary culture, become unmeasurable by the first or second passage, but can be subsequently reinduced by IL-1 $(31,47$, 48 ). That peptidase and protease expression are regulated differently is further illustrated by the ability of phorbol esters, in rabbit synovial cells, to downregulate NEP-24.11 mRNA expression while upregulating that of collagenase and stromelysin (46). This differential regulation could have important implications in therapeutic attempts to target inhibition of one, but not the other, class of enzymes. Identification of physiologically relevant factors or pharmacological agents that regulate peptidase activity within the joint may provide important insights into the pathogenesis and treatment of inflammatory 
arthritis. Glucocorticoids, for example, upregulate mRNA expression and functional activity of NEP-24.11 in transformed human tracheal epithelial cells (57) and this action may constitute an additional mechanism, in the joint, by which steroids exert antiinflammatory effects. Finally, an even broader role for these peptidases beyond the degradation of small peptides has been suggested by the ability of NEP-24.11, or an NEP24.11-like enzyme, to inactivate IL-1 (73) and to activate procollagenase (74), as well as by the ability of DAP IV to promote cell attachment $(75,76)$.

\section{Acknowledgments}

The authors thank Drs. Dennis Lennox, Michael Jacobs, Ronald Byank, and Kenneth Krackow for providing synovial specimens, Dr. Bruce Bochner for helpful suggestions and comments, and Ana Chow and Edward Siekierski for expert technical assistance.

This work was supported by grant numbers HL 32272 (D. Proud), HL 45791 (P. E. Ward), and Clinical Investigator Award K08 AR01856 (J. M. Bathon) from the National Institutes of Health and by a grant from the Arthritis Foundation, Maryland Chapter (J. M. Bathon).

\section{References}

1. Proud, D., and A. P. Kaplan. 1988. Kinin formation: mechanisms and role in inflammatory disorders. Annu. Rev. Immunol. 6:49-83.

2. Pernow, B. 1985. Role of tachykinins in neurogenic inflammation. J. Immunol. 135:812s-815s.

3. Melmon, K. L., M. E. Webster, S. E. Goldfinger, and J. E. Seegmiller. 1967. The presence of a kinin in inflammatory synovial effusions from arthritides of varying etiologies. Arthritis Rheum. 10:13-20.

4. Jasani, M. K., M. Katori, and G. P. Lewis. 1969. Intracellular enzymes and kinin enzymes in synovial fluid in joint diseases. Ann. Rheum. Dis. 28:497-511.

5. Eisen, V. 1970. Plasma kinins in synovial exudates. Br. J. Exp. Pathol. 51:322-327.

6. Lerner, U. H., I. L. Jones, and G. T. Gustafson. 1987. Bradykinin, a new potential mediator of inflammation-induced bone resorption. Arthritis Rheum. 30:530-540.

7. Bathon, J. M., D. Proud, K. Krackow, and F. M. Wigley. 1989. Preincubation of human synovial cells with IL-1 modulates prostaglandin $E_{2}$ release in response to bradykinin. J. Immunol. 143:579-586.

8. Marshall, K. W., B. Chiu, and R. D. Inman. 1990. Substance P and arthritis: analysis of plasma and synovial fluid levels. Arthritis Rheum. 33:87-90.

9. Gronblad, M., Y. T. Konttinen, L. Korkala, P. Liesi, M. Hukkanen, and J. M. Polak. 1988. Neuropeptides in synovium of patients with rheumatoid arthritis and osteoarthritis. J. Rheumatol. 15(12):1807-1810.

10. Pereira da Silva, J. A., and M. Carmo-Fonseca. 1990. Peptide containing nerves in human synovium: immunohistochemical evidence for decreased innervation in rheumatoid arthritis. J. Rheumatol. 17(12):1592-1599.

11. Konttinen, Y. T., R. Rees, M. Hukkanen, M. Gronblad, E. Tolvanen, S. J. Gibson, J. M. Polak, and D. A. Brewerton. 1990. Nerves in inflammatory synovium: immunohistochemical observations on the adjuvant arthritic rat model. $J$. Rheumatol. 17(12):1586-1591.

12. Bjurholm, A., A. Kreicbergs, M. Ahmed, and M. Schultzberg. 1990. Noradrenergic and peptidergic nerves in the synovial membrane of the Sprague-Dawley rat. Arthritis Rheum. 33:859-864.

13. Levine, J. D., R. Clark, M. Devor, C. Helms, M. A. Moskowitz, and A. I. Basbaum. 1984. Intraneuronal substance $P$ contributes to the severity of experimental arthritis. Science (Wash. DC). 226:547-549.

14. Lotz, M., D. A. Carson, and J. H. Vaughan. 1987. Substance P activation of rheumatoid synoviocytes: neural pathway in pathogenesis of arthritis. Science (Wash. DC). 235:893-895.

15. Lotz, M., J. H. Vaughan, and D. A. Carson. 1988. Effect of neuropeptides on production of inflammatory cytokines by human monocytes. Science (Wash. DC). 241:1218-1221.

16. Kimball, E. S., F. J. Persico, and J. L. Vaught. 1988. Substance P, neurokinin A, and neurokinin B induce generation of IL-1-like activity in P388D cells. J. Immunol. 141:3564-3569.

17. Lawrence, I. D., J. A. Warner, V. L. Cohen, W. C. Hubbard, A. Kagey-Sobotka, and L. M. Lichtenstein. 1987. Purification and characterization of human skin mast cells. Evidence for human mast cell heterogeneity. J. Immunol. 139:3062-3069.

18. Payan, D. G., and E. J. Goetzl. 1985. Modulation of lymphocyte function by sensory neuropeptides. J. Immunol. 135:783s-786s.

19. Lynch, D. R., and S. H. Snyder. 1986. Neuropeptides: multiple molecular forms, metabolic pathways, and receptors. Annu. Rev. Biochem. 55:773-799.

20. Ward, P. E. 1991. Metabolism of bradykinin and bradykinin analogs. In Bradykinin Antagonists. R. M. Burch, editor. Marcel Dekker, New York. 147170.

21. Bathon, J. M., and D. Proud. 1991. Bradykinin antagonists. Annu. Rev. Pharmacol. Toxicol. 31:126-162.

22. Vainio, U. 1966. A histochemical study on leucinoaminopeptidase activity in the synovial membrane of patients with rheumatoid arthritis. Ann. Rheum. Dis. 25:253-258.

23. Vainio, U. 1970. Leucineaminopeptidase in rheumatoid arthritis. Ann. Rheum. Dis. 29:434-438.

24. Sreedharan, S. P., E. J. Goetzl, and B. Malfroy. 1990. Elevated synovial tissue concentration of the common acute lymphoblastic leukaemia antigen (CALLA)-associated neutral endopeptidase (3.4.24.11) in human chronic arthritis. Immunology. 71:142-144.

25. Kamori, M., M. Hagihara, T. Nagatsu, H. Iwata, and T. Miura. 1991. Activities of dipeptidyl peptidase-II, dipeptidyl peptidase-IV, prolyl endopeptidase, and collagenase-like peptidase in synovial membrane from patients with rheumatoid arthritis and osteoarthritis. Biochem. Med. Metab. Biol. 45:154-160.

26. Harris, E. D., Jr. 1989. Pathogenesis of rheumatoid arthritis. In Textbook of Rheumatology, E. N. Kelley, E. D. Harris, Jr., S. Ruddy, and C. B. Sledge, editors. W. B. Saunders, Philadelphia, PA. 905-952.

27. Kurauchi, O., S. Mizutani, K. Okano, O. Narita, and Y. Tomoda. 1986. Purification and characterization of human placental microsomal aminopeptidase: immunological difference between placental microsomal aminopeptidase and pregnancy serum cystyl-aminopeptidase. Enzyme (Basel). 35:197-205.

28. Arnett, F. C., S. M. Edworthy, D. A. Bloch, D. J. McShane, J. F. Fries, N. S. Cooper, L. A. Healey, S. R. Kaplan, M. H. Liang, H. S. Luthra, et al. 1988. The American Rheumatism Association 1987 revised criteria for the classification of rheumatoid arthritis. Arthritis Rheum. 31:315-324.

29. Altman, R., E. Asch, D. Bloch, G. Bole, D. Borenstein, K. Brandt, W. Christy, T. D. Cooke, R. Greenwald, M. Hochberg, et al. 1986. Development of criteria for the classification and reporting of osteoarthritis: classification of osteoarthritis of the knee. Arthritis Rheum. 29:1039-1049.

30. Castor, C. W., R. K. Prince, and E. L. Dorstewitz. 1962. Characteristics of human fibroblasts cultivated in vitro from different anatomical sites. Lab. Invest. 11:703-713.

31. Dayer, J. M., S. M. Krane, G. G. Russell, and D. R. Robinson. 1976. Production of collagenase and prostaglandins by isolated adherent rheumatoid synovial cells. Proc. Natl. Acad. Sci. USA. 73:945-949.

32. Drapeau, G., A. Chow, and P. Ward. 1991. Metabolism of bradykinin agonists and antagonists by angiotensin converting enzyme and carboxypeptidase N. Peptides (Elmsford). 12:631-638.

33. Ward, P. E., A. Chow, and G. Drapeau. 1991. Metabolism of bradykinin agonists and antagonists by plasma aminopeptidase P. Biochem. Pharmacol 42:721-727.

34. Wang, L., S. Ahmad, I. Benter, A. Chow, S. Mizutani, and P. E. Ward. 1991. Differential processing of substance $P$ and neurokinin $A$ by plasma dipeptidyl(amino)peptidase IV, aminopeptidase $M$ and angiotensin converting enzyme. Peptides (Elmsford). 12:1357-1364.

35. Ward, P. E., I. F. Benter, L. Dick, and S. Wilk. 1990. Metabolism of vasoactive peptides by plasma and purified renal aminopeptidase M. Biochem. Pharmacol. 40:1725-1732.

36. Ahmad, S., and P. E. Ward. 1990. Role of aminopeptidase activity in the regulation of the pressor activity of circulating angiotensin. J. Pharmacol. Exp. Ther. 252:643-650.

37. McDonald, J. K., and A. J. Barrett. 1986. Mammalian Proteases: A Glossary and Bibliography. Vol. 2. Academic Press, New York.

38. Roques, B. P., M. C. Fournie-Zaluski, D. Florentin, G. Waksman, A. Sassi, P. Chaillet, H. Collado, and J. Costentin. 1982. New enkephalinase inhibitors as probes to differentiate "enkephalinase" and angiotensin converting enzyme active sites. Life Sci. 31:1749-1752.

39. Umezawa, H., T. Aoyagi, K. Ogawa, H. Naganawa, M. Hamada, and T. Takeuchi. 1984. Diprotins A and B, inhibitors of dipeptidylaminopeptidase IV. J. Antibiotics (Tokyo). 37:422-425.

40. Hudgin, R. L., S. E. Charleson, M. Zimmerman, R. Mumford, and P. L. Wood. 1981. Enkephalinase: selective peptide inhibitors. Life Sci. 29:2593-2601. 41. Ward, P. E. 1984. Immunoelectrophoretic analysis of vascular membrane-bound angiotensin I converting enzyme, aminopeptidase $M$ and dipeptidyl(amino)peptidase IV. Biochem. Pharmacol. 33:3183-3193.

42. Bochner, B. S., A. A. McKelvey, R. P. Schleimer, J. E. K. Hildreth, and D. W. MacGlashan, Jr. 1989. Flow cytometric methods for the analysis of human basophil surface antigens and viability. J. Immunol. Methods. 125:265-271. 
43. Matsas, R., A. J. Kenny, and A. J. Turner. 1984. The metabolism of neuropeptides: the hydrolysis of peptides including enkephalins, tachykinins and their analogues by endopeptidase-24.11. Biochem. J. 223:433-440.

44. Knapp, W. 1989. Leucocyte Typing IV: White Cell Differentiation Antigens. Oxford University Press, New York. 1182 pp.

45. Chercuitte, F., D. A. Beaulieu, P. Poubelle, and F. Marceau. 1987. Carboxypeptidase $\mathrm{N}$ (Kininase I) activity in blood and synovial fluid from patients with arthritis. Life Sci. 41:1225-1232.

46. Werb, Z., and E. J. Clark. 1989. Phorbol diesters regulate expression of the membrane neutral metalloendopeptidase (EC 3.4.24.11) in rabbit synovial fibroblasts and mannary epithelial cells. J. Biol. Chem. 264:9111-9113.

47. Dayer, J.-M., B. de Rochemonteix, B. Burrus, S. Demczuk, and C. A Dinarello. 1986. Human recombinant interleukin 1 stimulates collagenase and prostaglandin $\mathrm{E}_{2}$ production by human synovial cells. J. Clin. Invest. 77:645648.

48. Unemori, E. N., M. S. Hibbs, and E. P. Amento. 1991. Constitutive expression of a $92-\mathrm{kD}$ gelatinase (type $\mathrm{V}$ collagensae) by rheumatoid synovia fibroblasts and its induction in normal human fibroblasts by inflammatory cytokines. J. Clin. Invest. 88:1656-1662.

49. Letarte, M., S. Vera, R. Tran, J. B. L. Addis, R. J. Onizuka, E. J. Quackenbush, C. V. Jongeneedl, and R. R. McInnes. 1988. Common acute lymphocytic leukemia antigen is identical to neutral endopeptidase. J. Exp. Med. 168:12471253.

50. Kenny, A. J., A. G. Booth, S. G. George, J. Ingram, D. Kershaw, E. J. Wood, and A. R. Young. 1976. Dipeptidyl peptidase IV, a kidney brush-border serine peptidase. Biochem. J. 155:169-182.

51. Kato, T., T. Nagatsu, K. Fukasawa, M. Harada, I. Nagatsu, and S. Sakakibara. 1978. Successive cleavage of N-terminal Arg-Pro and Lys-Pro from substance $\mathrm{P}$ but no release of Arg-Pro from bradykinin, by X-Pro dipeptidylaminopeptidase. Biochim. Biophys. Acta. 525:417-422.

52. Palmieri, F. E., and P. E. Ward. 1983. Mesentery vascular metabolism of substance P. Biochim. Biophys. Acta. 755:522-525.

53. Look, A. T., R. A. Ashmun, L. H. Shapiro, and S. C. N. Peiper. 1989. Human myeloid plasma membrane glycoprotein CD13 (gp150) is identical to aminopeptidase N. J. Clin. Invest. 83:1299-1307.

54. Bathon, J. M., D. C. Manning, D. W. Goldman, M. C. Towns, and D. Proud. 1992. Characterization of kinin receptors on human synovial cells and upregulation of receptor number by interleukin-1. J. Pharmacol. Exp. Ther. 260:384-392.

55. Appelboom, T., V. de Maertelaer, E. de Prez, J.-P. Hauzeur, and M Deschodt-Lanckman. 1991. Enkephalinase: a physiologic neuroimmunomodulator detected in the synovial fluid. Arthritis Rheum. 34:1048-1051.

56. Hojima, Y., C. G. Cochrane, R. C. Wiggins, K. K. Austen, and R. L. Stevens. 1984. In vitro activation of the contact (Hageman factor) system of plasma by heparin and chondroitin sulfate E. Blood. 63:1453-1459.

57. Borson, D. B., and D. C. Gruenert. 1991. Glucocorticoids induce neutral endopeptidase in transformed human tracheal epithelial cells. Am. J. Physiol. 260:L83-L89.

58. Sharma, J. N., I. J. Zeitlin, S. D. Deodhar, and W. W. Buchanan. 1983 Detection of kallikrein-like activity in inflamed synovial tissue. Arch. Int. Pharmacodyn. 262:279-286.

59. Selwyn, B. M., C. D. Figueroa, E. Fink, A. Swan, P. A. Dieppe, and K. D.
Bhoola. 1989. A tissue kallikrein in the synovial fluid of patients with rheumatoid arthritis. Ann. Rheum. Dis. 48:128-133.

60. Bausback, H. H., and P. E. Ward. 1986. Degradation of low molecular weight opioid peptides by vascular plasma membrane aminopeptidase M. Biochim. Biophys. Acta. 882:437-444.

61. Churchill, L., H. H. Bausback, M. E. Gerritsen, and P. E. Ward. 1987. Metabolism of opioid peptides by cerebral microvascular aminopeptidase $\mathbf{M}$. Biochim. Biophys. Acta. 923:35-41.

62. Russell, N. J. W., H.-G. Schaible, and R. F. Schmidt. 1987. Opiates inhibit the discharges of fine afferent units from inflamed knee joint of the cat. Neurosci. Lett. 76:107-112.

63. Schmidt, C., J. Peyroux, F. Noble, M. C. Fournie-Zaluski, and B. P. Roques. 1991. Analgesic responses elicited by endogenous enkephalins (protected by mixed peptidase inhibitors) in a variety of morphine-sensitive noxious tests. Eur. J. Pharmacol. 192:253-262.

64. Stein, C., A. H. S. Hassan, R. Przewlocki, C. Gramsch, K. Peter, and A. Herz. 1990. Opioids from immunocytes intereact with receptors on sensory nerves to inhibit nociception in inflammation. Proc. Natl. Acad. Sci. USA. 87:5935-5939.

65. Russell, N. J. W., A. Jamieson, T. S. Callen, and M. J. Rance. 1985. Peripheral opioid effects upon neurogenic plasma extravasation and inflammation. Br. J. Pharmacol. 86:788-789.

66. Van Epps, D. E., and L. Saland. 1984. Beta-endorphin and met-enkephalin stimulate human peripheral blood mononuclear cell chemotaxis. J. Immunol. 132:3046-3053.

67. Gilman, S. C., J. M. Schwartz, R. J. Milner, F. E. Bloom, and J. D. Feldman. 1982. Beta-endorphin enhances lymphocyte proliferative responses. Proc. Natl. Acad. Sci. USA. 79:4226-4230.

68. Wybran, J. 1985. Enkephalins and endorphins as modifiers of the immune system: present and future. Fed. Proc. 44:92-94.

69. Hughes, J. 1983. Biogenesis, release and inactivation of enkephalins and dynorphins. Br. Med. Bull. 39:17-24.

70. Palmieri, F. E., H. H. Bausback, and P. E. Ward. 1989. Metabolism of vasoactive peptides by vascular endothelium and smooth muscle aminopeptidase M. Biochem. Pharmacol. 38:173-180.

71. Hegen, M., G. Niedobitek, C. E. Klein, H. Stein, and B. Fleischer. 1990. The $\mathrm{T}$ cell triggering molecule $\mathrm{Tp} 103$ is associated with dipeptidyl aminopeptidase IV activity. J. Immunol. 144:2908-2914.

72. Harris, E. D., Jr. 1990. Rheumatoid arthritis: pathophysiology and implications for therapy. N. Engl. J. Med. 322:1279-1289.

73. Pierart, M. E., T. Najdovski, T. E. Appelboom, and M. M. DeschodtLanckman. 1988. Effect of human endopeptidase 24.11 ("enkephalinase") on IL-1-induced thymocyte proliferation activity. J. Immunol. 140:3808-3811.

74. Unemori, E. N., and Z. Werb. 1988. Collagenase expression and endogenous activation in rabbit synovial fibroblasts stimulated by the calcium ionophore A23187. J. Biol. Chem. 263:16252-16259.

75. Bauvois, B. 1988. A collagen-binding glycoprotein on the surface of mouse fibroblasts is identified as dipeptidyl peptidase IV. Biochem. J. 252:723731.

76. Piazza, G. A., H. M. Callanan, J. Mowery, and D. C. Hixson. 1989. Evidence for a role of dipeptidyl peptidase IV in fibronectin-mediated interactions of hepatocytes with extracellular matrix. Biochem. J. 262:327-334. 